\title{
PENERAPAN SISTEM MANAJEMEN KINERJA PEGAWAI DI BANDARA UDARA LAGA LIGO BUA KABUPATEN LUWU
}

\author{
Kiki Damayanti $^{1}$, Mappamiring ${ }^{2}$, Musliha Karim ${ }^{3}$ \\ 1) Jurusan Ilmu Administrasi Negara Unismuh Makasssar \\ 2) Jurusan Ilmu Administrasi Negara Unismuh Makassar \\ 3) Jurusan Ilmu Administrasi Negara Unismuh Makassar
}

\begin{abstract}
This study aimed to describe the implementation of management system of employee performance at Laga Ligo Bua Airport, Luwu regency. The type of the research is descriptive qualitative which involved 10 emplyees as respondent. The teehnique of data analysis used is qualitative-descriptive wich is presented in question, responses and interpretations gained from direct observation and interviev. The results of the research reveal that the implementation of the employec performance management system at Laga Ligo Bua Airport Luwu regerency generally was not effective. It can be identified from the indicators: a) the commitment and policies are implemented properly, b) the plan operaetes well, c) implementation is optimal, d) the inhibiting factors are not in accordance with the indicators that have been set, and e) the supporting factors operates well.
\end{abstract}

Keywords: management, performance

\begin{abstract}
ABSTRAK
Penelitian ini bertujuan untuk menguraikan bagaimana Penerapan Sistem Manajemen Kinerja Pegawai Di Bandar Udara Laga Ligo Bua Kabupaten Luwu. Jenis penelitian yang digunakan dalam penelitian ini adalah kualitatif dengan 10 responden. Tehnik pengumpulan data dilakukan melalui obsevasi dan wawancara. Teknis analisis data yakni analisis deskriptif kualitatif yang dinyatakan dalam bentuk-bentuk pertanyaan, tanggapantanggapan serta tafsiran yang diperoleh dari observasi dan wawancara langsung. Hasil penelitian ini menunjukan bawah secara umum belum berjalan dengan efektif. Hal tersebut dapat dilihat dari indikator (a) komitmen dan kebijakan berjalan dengan lancar, (b) perencanaan berjalan dengan baik, (c) penerapan berjalan dengan baik,(d) faktor penghambat tidak berjalan sesuai indikator yang telah di tetapkan serta (e) faktor pendukung berjalan dengan baik.
\end{abstract}

Kata kunci: Manajemen, Kinerja 


\section{PENDAHULUAN}

Pembangunan Nasional dewasa
ini berjalan seiring dengan
perkembangan industri yang pesat dan
mandiri dalam rangka mewujudkan
industrialisasi yang ditandai dengan
mekanisme, elektrefikasi dan

modernisasi. Karena kebutuhan mobilitas yang tinggi tersebut, maka diperlukan jenis transportasi, penyedia transportasi dan fasilitas yang dapat menyesuaikan dengan kebutuhan manusia saat ini. Karena banyaknya pengunaan Pesawat terbang maka harus diperhatikan pula mengenai Bandar Udara sebagai tempat fasilitas pesawat terbang dan fasilitas penunjang lainnya.

Kinerja dalam suatu organisasi senantiasa diupayakan peningkatannya karena meningkatnya kinerja tidak saja akan membawa pengaruh langsung kepada organisasi, namun akan berdampak terhadap peningkatan kemampuan pegawai. Selain itu kinerja yang meningkat akan menciptakan suasana yang lebih kondusif yang pada akhirnya menimbulkan persaingan yang sehat antar pegawai yang berdampak pada pengembangan diri pegawai masingmasing. Dengan kata lain apabila kinerja diwujudkan, akan mendukung tercapainya tujuan secara efektif dan efesien yang pada akhirnya menciptakan percepatan, kecepatan, efektifitas dan efesiensi kerja di lingkungan organisasi bersangkutan.

Sistem manajemen keselamatan dan kesehatan kerja mendapatkan perhatian yang sangat penting dewasa ini karena masih tingginya angka kecelakaan kerja. Manajemen kinerja bertujuan menciptakan sistem keselamatan dan kesehatan kerja ditempat kerja dengan melibatkan unsur manajemen, tenaga kerja, kondisi lingkungan kerja yang terintegrasi dalam rangkah mencegah dan mengurangi kecelakaan dan penyakit akibat kerja serta terciptanya tempat kerja yang aman. Pasal 87 UU tersebut mewajibkan setiap perusahaan menerapkan manajemen kinerja pegawai sebagai bagian dari manajemen perusahaan, dan bagi yang 
tidak menerapkannya akan diberi sanksi.

Penyebab Utama kecelakaan kerja adalah kurang optimalnya pelaksanaan kinerja, sedangkan penyebab Sebenarnya adalah Mis Management yang artinya manajemen tidak melakukan upaya pencegahan kecelakaan kerja seiring dengan kegiatan manajemen perusahaan.

Penyusunan tugas akhir ini, akan dievaluasi Bagaimana Penerapan Sistem Manajemen Kinerja Pegawai pada Bandar Udara Laga Ligo Bua Kabupaten Luwu. Evaluasi penerapan Kinerja Pegawai dilaksanakan sebagaimana telah disebutkan

\section{Berdasarkan permasalahan}

diatas, maka penulis tertarik untuk mengangkat masalah tersebut sebagai bahan penelitian dengan judul "Penerapan Sistem Manajemen Kinerja Pegawai Di Bandar Udara Laga Ligo Bua Kabupaten Luwu". Bawah dalam penerapan sistem manajemen kinerja sangat penting penerapan sistem manajemen fungsinya dapat diklasifikasikan sebagai berikut: 1) Komitmen dan
Kebijakan, 2) Perencanaan, 3) Penerapan

Wibowo, 2007 menyatakan bawah Manejemen kinerja sebagai proses komunikasi yang dilakukan secara terus menerus dalam kemitraan antara karyawan dengan atasan langsungnya untuk mendapatkan hasil yang lebih baik dari organisasi, tim dan individu dengan cara memahami dan mengelola kinerja dalam suatu kerangka tujuan, standar, dan persyaratan-persyaratan atribut yang disepakati antara manajer dan karyawan yang menyangkut penetapan tujuan, memberikan umpan balik baik dari manajer kepada karyawan maupun sebaliknya.

Manajemen kinerja merupakan dasar dan kekuatan pendiri yang berada di belakang semua keputusan organisasi, Amstrong (2003:12) menyatakan bawah manajemen kinerja adalah proses sistematis untuk memperbaiki kinerja operasional dengan mengembangkan kinerja individual dan tim. Merupakan sarana untuk mendapatkan hasil lebih baik dengan memahami dan mengelolah 
kinerja dalam kerangka kerja yang disepakati tentang tujuan rencana, standar dan persyaratan kompotensi.

Amstrong (2009: 9) Perumusan tersebut menunjukan bawah Amstrong lebih menekankan kedudukan manajemen kinerja sebagai proses sistematis untuk memperbaikai kinerja, bukan hanya sebagai sarana untuk mendapatkan hasil lebih baik. Dengan demikian, manajemen kinerja dalam mencapai hasil dilakukan melalui proses sistematis.

Wungu dan Brotoharsojo (2003:58) mengemukakan bawah kinerja kuantitas dan kualitas hasil kerja yang dicapai oleh pegawai perbandingan terhadap target dan sasaran kerja individu pada jabatannya.

Kinerja seseorang merupakan kombinasi dan kemampuan, usaha dan kesempatan yang dapat dinilai dari hasil kerjanya. Menurut George R. Terry (2000:344) a.) Perencanaan adalah proses penentuan tujuan atau sasaran yang hendak dicapai dan menetapkan jalan dan sumber yang diperlukan untuk mencapai tujuan itu seefisien dan seefektif mungkin. b) Pengorganisasian ialah keseluruhan proses pengelompokkan orang-orang, alat-alat, tugas-tugas, serta wewenang dan tanggung jawab sedemikian rupa sehingga tercipta suatu organisasi yang dapat digerakkan sebagai suatu kesatuan yang utuh dan bulat dalam rangka pencapaian tujuan yang telah ditentukan sebelumnya, c) Pelaksanaan atau penggerakan dapat diartikan sebagai keseluruhan usaha, cara, teknik dan metode untuk mendorong para anggota organisasi agar mau dan ikhlas bekerja dengan sebaik mungkin demi tercapainya organisasi dengan efisien, efektif dan ekonomis. d) Controlling atau pengawasan merupakan fungsi manajerial dasar yang sengaja didesain untuk maksud tertentu sesuai dengan tujuan kontrol yang diharapkan, sehingga manajer dapat mengetahui efektivitas sumbersumber informasi yang ada dalam organisasinya, efektivitas aktifitas kelompok, serta efektivitas aktifitas setiap individu anggota organisasinya. 
Anggaran (2008:7), ikut berperan dalam pencapaian tujuan manajemen kinerja merupakan suatu proses strategis dan terpadu yang menunjang keberhasilan organisasi melalui pengembangan performansi aspek-aspek yang menunjang keberadaan suatu organisasi. Pada implementasinya, manajemen kinerja tidak hanya berorientasi pada salah satu aspek, melainkan aspek-aspek terintegrasi dalam mendukung jalannya suatu organisasi.

Dessler (2003:322) definisi Manajemen Kinerja adalah Proses mengonsolidasikan penetapan tujuan, penilaian, dan pengembangan kinerja kedalam satu sistem tunggal bersama, yang bertujuan memastikan kinerja karyawan mendukung tujuan strategis perusahaan. Udekusuma (2007:3) Manajemen kinerja adalah suatu proses manajemen yang dirancang untuk menghubungkan tujuan organisasi dengan tujuan individu sedemikian rupa, sehingga baik tujuan individu maupun tujuan perusahaan dapat bertemu. Dalam hal ini bagi pekerja bukan hanya tujuan individunya yang tercapai tetapi juga organisasi, yang membuat dirinya termotivasi serta mendapat kepuasan yang lebih besar. Tujuan Manajemen Kinerja menurut Baron, 2005;22 Wibisono, 2006:32 Mengatur kinerja organisasi dengan lebih terstruktur dan terorganisir. Mengetahui seberapa efektif dan efisien suatu kinerja organisasi.

Membantu penentukan keputusan organisasi yang berkaitan dengan kinerja organisasi, kinerja tiap bagian dalam organisasi, dan kinerja individual. Meningkatkan kemampuan organisasi secara keseluruhan dengan perbaikan berkesinambungan. Mendorong karyawan agar bekerja sesuai prosedur, dengan semangat, dan produktif sehingga hasil kerja optimal. Penerapan sistem manajemen kinerja pegawai menurut M. Sukaelan, 2013:45) yaitu :

Komitmen dan Kebijakan menyebutkan bawah komitmen adalah niat atau tekad untuk menjelaskan sesuatu yang menjadi daya dorong yang sangat kuat untuk mencapai tujuan. Tekad dan keinginan tersebut, 
akan tercermin dalam sikap dan tindakan tentang K3. Tanpa komitmen dari semua unsur dalam organisasi, khususnya parah pemimpin, pelaksanaan K3 tidak akan berjalan dengan baik. Berdasarkan Permenaker RI No. Per-05/MEN/1996 dalam komitmen dan kebijakan.

Perencanaan Perusahaan harus membuat perencanaan yang efektif guna mencapai keberhasilan penerapan Sistem Manajemen dengan sasaran dan indikator kinerja yang diterapkan dengan mempertimbangkan identifikasi sumber bahaya penilaian dan pengendalian resiko sesuai dengan persyaratan perundangan yang berlaku serta hasil pelaksanaan tinjauan awal terhadap keselamatan dan kesehatan kerja.

Penerapan menetapkan kebijakan secara efektif dengan mengembangkan kemampuan dan mekanisme pendukung yang di perlukan untuk mencapai kebijakan, tujuan dan sasaran penerapan. Perusahaan harus menyediakan personil yang memiliki kualitas, sarana yang memadai sesuai sistem
Manajemen yang diterapkan dengan membuat prosedur yang dapat memantau manfaat yang akan di dapat maupun biaya yang harus dikeluarkan. Untuk pembuktian penerapan, perusahaan data yang diperlukan melalui observasi, dokumentasi, wawancara dengan Karyawan Yang Ada Di Bandar Udara Laga Ligo Bua Kabupaten Luwu.

Teknik analisis data dalam penelitian kualitatif, dilakukan pada saat pengumpulan data yang berlangsung, dan setelah selesai pengumpulan data dalam periode tertentu dengan tahap reduksi data yang diperoleh dari lapangan, dan tahap penarikan kesimpulan dan verivikasi data, yang mendukung tahap pengumpulan data.

Teknik analisis data dalam penelitian kualitatif, dilakukan pada saat pengumpulan data yang berlangsung, dan setelah selesai pengumpulan data dalam periode tertentu dengan tahap reduksi data yang diperoleh dari lapangan, dan 
tahap penarikan kesimpulan dan verivikasi data, yang mendukung tahap pengumpulan data.

Teknik analisis data dalam penelitian kualitatif, dilakukan pada saat pengumpulan data yang berlangsung, dan setelah selesai pengumpulan data dalam periode tertentu dengan tahap reduksi data yang diperoleh dari lapangan, dan tahap penarikan kesimpulan dan verivikasi data, yang mendukung tahap pengumpulan data.

\section{METODE PENELITIAN}

Penelitian ini dilakukan di Bua Kabupaten Luwu berlangsung selama 2 bulan setelah menyelesaikan seminar proposal perbaikan dan pengurusan izin penelitian. Alasan memilih Bua

Kabupaten Luwu. Penelitian lokasi penelitian ini ditentukan atas dasar pertimbangan karena melihat kondisi sistem manajemen kinerja pegawai di Bandar Udara Laga Ligo Bua yang kurang efektif. Jenis penelitian ini adalah penelitian Kualitatif. Tipe penelitian ini adalah Fenomenologi Sumber data yang digunakan dalam penelitian ini mencakup data primer dan data sekunder. Informan dalam penelitian ini sebanyak 10 responden Teknik pengumpulan data yang merupakan langkah yang sangat penting dalam penelitian.Pengumpulan data adalah prosedur yang sistematik dan standar untuk memperoleh

Pengabsahan data yang terdiri dari Trianggulasi Sumber yang membandingkan dan mengecek balik derajat kepercayaan suatu informasi yang diperoleh melalui waktu dan alat yang berada dalam penelitian kualitatif.

Trianggulasi Teknik data yang di dari Bandar Udara Laga Ligo Bua Kabupaten Luwu.

\section{HASIL DAN PEMBAHASAN}

Bawah dalam mencapai tujuan kinerja, para pegawai harus menjalankan tugasnya sesuai dengan kemampuan yang mereka miliki dan pimpinan mempunyai peran penting untuk mengkoordinir bawahan dan memiliki kemampuan mempengaruhi 
dan menggerakan para bawahannya unutk bekerja mencapai tujuan.

Dalam suatu organisasi, kepemimpinan memegang peranan yang sangat penting, pemimpin harus dapat mempengaruhi dan menggerakan bawahan agar dapat mencapai tujuan organisasi secara efektif dan efesien, yaitu suatu semangat kerja maksimal. Untuk mencapai tujuan organisasi seperti apa yang diharapkan maka sangat dibutuhkan suatu gaya kepemimpinan yang sesuai agar dalam penerapan sistem manajemen kinerja pegawai dapat berjalan sesuai apa yang telah direncanakan sebelumya dan jaringan transportasi udara yang handal,optimal dan terintegarasi.

Mewujudkan kelembagaan yang efektif, efisien didukung oleh SDM yang professional dan peraturan perundang-undangan yang kompreshensif serta terjamin kepastian hukum.

Menetapkan tujuan kinerja
sangat di perlukan sebagai proses
manajemen yang memastikan bawah
setiap pegawai tahu peran apa yang

harus mereka lakukan dan apa hasil apa yang perlu mereka capai untuk mencapai target. Komitmen harus di sertai dengan motif karena kinerja pegawai di tentukan oleh tujuan yang ingin dicapai dan untuk melakukannya di perlukan adanya motivasi kerja karyawan. Tanpa dorongan motifasi untuk mencapai tujuan, kinerja tidak akan berjalan dan dalam melaksanakan pekerjaan tersebut seorang pemimpin harus mampu memberikan kebijakan yang dapat membuat kinerja karyawan lebih optimal lagi dalam menyelesaikan tugas-tugas yang di embankan kepadanya.

Penerapan Sistem Manajemen Kinerja Pegawai adalah kinerja yang mengikuti tata cara atau prosedur sesuai standar yang telah ditetapkan. Akan tetapi didalam kinerja tersebut harus memiliki beberapa kriteria agar peningkatan produktifitas sehingga apa yang diharapakan bisa berjalan sesuai apa yang di inginkan. Untuk meningkatkan kinerja yang baik harus intropeksi diri demi tercapainya kinerja yang lebih baik kedepannya, bekerja sesuai posisi, porsi, dan jobnya 
masing-masing. Berdasarkan variabel yang terdapat di bagan kerangka fikir yaitu, a) komitmen dan kebijakan, b) Perencanaan, c) penerapan, d) faktor penghambat, e) faktor pendukung.

Hal tersebut tidaklah semudah membalikkan telapak tangan tetapi mesti ada peran langsung ke ikut sertaan manajemen untuk bisa variable pertama yaitu Komitmen dan kebijakan yang terdiri dari satu sub variable yaitu : a) Kepemimpinan dan komitmen b) Tinjauan Ulang c) Kebijakan dan Keselamatan dan kesehatan variable tersebut akan dijelaskan dibawah ini, Komitmen dan Kebijakan dawah mencapai tujuan kinerja, para pegawai harus menjalankan tugasnya sesuai dengan kemampuan yang mereka miliki dan pimpinan mempunyai peran penting untuk mengkoordinir bawahan dan memiliki kemampuan mempengaruhi dan menggerakan para bawahannya unutk bekerja mencapai tujuan. Dalam suatu organisasi, kepemimpinan memegang peranan yang sangat penting, pemimpin harus dapat mempengaruhi dan menggerakan bawahan agar dapat mencapai tujuan organisasi secara efektif dan efesien, yaitu suatu semangat kerja maksimal. Untuk mencapai tujuan organisasi seperti apa yang diharapkan maka sangat dibutuhkan suatu gaya kepemimpinan yang sesuai.

Standar komitmen dan kebijakan kinerja yang telah ditetapkan di kantor ini sangat penting untuk membimbing perilaku pekerja untuk menyelesaikan standar yang telah dibangun dan menyediakan dasar bagi kinerja-kinerja pekerja dapat dinilai secara efektif dan jujur. Sehingga dalam melaksanakan tugas terlebih dahulu membuat standar komitmen dan kebijakan yang telah disepakati agar karyawan juga mampu termotivasi untuk mencapai hasil kerja yang baik adanya suatu indikator kinerja (key performance indicator) yang terukur secara jelas batas waktunya. Ukuran ini harus dapat menjawab berbagai permasalahan yang dihadapi oleh organisasi tersebut. Jika perusahaan yang berorientasi pada profit, maka ukurannya adalah ukuran 
finansial seperti omset penjualan, laba bersih, pertumbuhan penjualan dan lain-lain. Sedangkan pada organisasi nirlaba seperti organisasi pemerintahan maka ukuran kinerjanya adalah berbagai bentuk pelayanan kepada masyarakat.

Komitmen dan kebijakan dalam penerapan sistem manajemen kinerja bawah dalam mencapai tujuan kinerja, para pegawai harus menjalankan tugasnya sesuai dengan kemampuan yang mereka miliki dan pimpinan mempunyai peran penting untuk mengkoordinir bawahan dan memiliki kemampuan mempengaruhi dan menggerakan para bawahannya unutk bekerja mencapai tujuan. Dalam suatu organisasi, kepemimpinan memegang peranan yang sangat penting, pemimpin harus dapat mempengaruhi dan menggerakan bawahan agar dapat mencapai tujuan organisasi secara efektif dan efesien, yaitu suatu semangat kerja maksimal. Untuk mencapai tujuan organisasi seperti apa yang diharapkan maka sangat dibutuhkan suatu gaya kepemimpinan yang sesuai, Perencanaan konsep perencanaan ialah pengambilan keputusan tentang apa yang dikerjakan, bagaimana mengerjakannya, kapan mengerjakannya, siapa yang mngerjakannya dan bagaimana mengukur keberhasilan pelaksanaannya. Mengetahui hal tersebut maka penulis memilih 3 (tiga) sub variable sebagai tolak ukur pendekatan ini, identifikasi bahaya dan pengendalian resiko, tujuan dan sasaran kebijakan dalam membuat perancanaan yang efektif guna mencapai penerapan sistem kebijakan keselamatan dan kesehatan kerja cukup jelas dan dapat diukur sehingga pemimpin dapat bertanggung jawab dan sistem manajemen keselmatan dan kesehatan kerja telah di terapkan dengan baik. bawah dalam mengimlementasikan terlebih dahulu risiko-risiko yang mungkin akan di alami oleh perusahaan maka dilakukan evaluasi atas masingmasing resiko ditinjau dari severity dan frekuensinya. Pengengendalian resiko perlu ditentukan langkah 
pengendalian yang dipilih dari berbagai cara seperti memlih teknologi pengendalian seperti eliminasi, subtitusi peralatan mesin atau pelindug diri.

Komitmen dalam suatu organisasi sangatlah erat kaitannya dengan dedikasi kerja karyawan demi tercapainya suatu tujuan yang ingin di capai agar berusahaan tersebur dapat berkembang dengan baik. Ada dua hal yang perlu dicantumkan dalam kontrak kinerja yaitu sasaran akhir yang ingin dicapai (lag) serta program kerja untuk mencapainya (lead). Keduanya perlu dicantumkan supaya pada saat evaluasi nanti berbagai pihak bersikap secara fair, dan tidak melihat hasil akhir semata, namun juga proses kerjanya. Bisa saja seorang bawahan belum mencapai semua hasil kerja yang ditargetkan, tetapi dia sudah melaksanakan semua program kerja yang sudah digariskan. Tentu saja atasan tetap harus memberikan reward untuk dedikasinya, walaupun sasaran akhir belum tercapai. Hal ini juga bisa menjadi dasar untuk perbaikan di masa mendatang (continuous improvement).
Kebijakan manajemen kinerja pegawai tidak akan berhasil jika tidak di dukung oleh semua pihak dalam organisasi. Sebuah perusahaan pasti harus ada orang atau sekelompok orang yang bisa mengatur jalannya operasional perusahaan. Ibaratnya sebuah kendaraan bermotor, manajeman merupakan pengemudinya yang menjalankan dan mengarahkan arah ke mana akan pergi dan berlabuh. Tugas ini sangat penting dan cukup berat. Oleh karena itu, manajemen biasanya dipegang oleh beberapa orang di sebuah perusahaan. Orangorang tersebut berkompeten di bidangnya, sehingga mampu untuk mengambil kebijakan strategis dalam sebuah perusahaan. Manajemen juga harus bertanggung jawab penuh atas berhasil tidaknya sebuah operasional perusahaan. Mereka akan dimintai pertanggungjawabannya oleh pemilik perusahaan, yang mungkin tidak terlibat dalam sebuah tugas menajemen.

Proses manajemen yang memastikan bawah setiap pegawai tahu peran apa yang harus mereka 
lakukan dan apa hasil apa yang perlu mereka capai untuk mencapai target. Komitmen harus di sertai dengan motif karena kinerja pegawai di tentukan oleh tujuan yang ingin dicapai dan untuk melakukannya di perlukan adanya motivasi kerja karyawan. Tanpa dorongan motifasi untuk mencapai tujuan, kinerja tidak akan berjalan sesuai standar komitmen dan kebijakan kinerja yang telah ditetapkan di kantor ini sangat penting untuk membimbing perilaku pekerja untuk menyelesaikan standar yang telah dibangun.

Menyediakan dasar bagi kinerja-kinerja pekerja dapat dinilai secara efektif dan jujur, komitmen dan kebijakan kinerja pegawai harus dibuat untuk pekerjaan itu sendiri tanpa memandang siapa yang menduduki pekerjaan. Maka dari itu, harus ada satu komitmen dan kebijakan untuk jenis pekerjaan tertentu, bukan satu set untuk setiap orang melakukan pekerjaan.

Penerapan menetapkan kebijakan secara efektif dengan mengembangkan kemampuan dan mekanisme pendukung yang di perlukan untuk mencapai kebijakan, tujuan dan sasaran penerapan. Mengetahui hal tersebut maka penulis memilih 2 (dua) sub variable sebagai tolak ukur pendekatan ini yaitu: menciptakan hubungan harmonis bagi karyawan dan perusahaan, peralatan mesin baik sehingga alat semakin panjang umur.

Hubungan industrial dalam arti yang lebih luas berarti adanya hungan antara semua pihak yang terkaitan ataupun memiliki kepentingan atas suatu proses produksi atas suatu proses produksi di suatu perusahaan sehingga hubungan industry yang perlu di bangun tidak hanya antara pengusaha dengan karyawan tetapi juga mencakup hubungannya dengan pemerintah serta masyarakat memadukan tiap-tiap prinsip dan tujuan perlu adanya niat baik serta berusaha serta dapat menyelesaikan berbagai perseolan yang muncul sehingga bias di capai suatu solusi terbaik dan tidak merugikan pihak manapun. 
Seorang pemimpin harus meningkatkan loyalitas kerja dengan menumbuhkan kesedian berkorban dengan melalui lebih banyak penghargaan yang di hubungkan dengan kontribusi dari masing-masing individu pengawai sehingga bawahan dapat melihat dari sudut pandang kepuasan yang positif terhadap kinerja. Menerapkan konsep manajemen SDM berbasis kompetensi. Umumnya organisasi yang berkinerja tinggi memiliki kamus kompetensi dan menerapkan kompetensi itu tersebut kepada hal-hal yang penting, seperti manajemen kinerja, rekruitmen, seleksi, pendidikan, pengembangan pegawai, dan promosi. Kompetensi ini meliputi kompetensi inti organisasi, kompetensi perilaku, dan kompetensi teknis yang spesifik dalam pekerjaan. Jika kompetensi ini sudah dibakukan dalam organisasi, maka kegiatan manajemen SDM akan menjadi lebih transparan, dan pimpinan organisasi juga dengan mudah mengetahui kompetensi apa saja yang perlu diperbaiki untuk membawa organisasi menjadi berkinerja tinggi.
Faktor pendukung penilaian kinerja, yang harus dipahami oleh manajemen adalah bawah penilaian kinerja itu bertujuan untuk memberikan feed back dalam rangka meningkatkan kinerja karyawan itu sendiri. Dengan demikian, pelaksanaan penilaian kinerja yang baik dan adil bagi karyawan merupakan tanggung jawab manajemen. Agar penilaian kinerja dapat tercapai tujuannya.

Melaksanakan kegiatannya secara optimal, suatu organisasi memerlukan ketersedian sarana dan prasarana yang memadai baik dalam jumlah maupun kualitasnya. untuk membentuk seseorang karyawan agar perusahaan semakin mengikuti perkembangan zaman maka yang dibutuhkan adalah tingkat pendidikan karyawan yang di butuhkan oleh perusahaan dalam pendidikan terdapat proses yang terus berjalan dan bukan sesaat saja.

Faktor penghambat tenaga kerja atau karyawan adalah merupakan faktor produksi yang bersifat senantiasa bergerak dan selalu berubah-ubah, mempunyai akal dan 
perasaan serta motivasi, jika tenaga kerja sebagai faktor produksi merasa senang bekerja dengan penuh semangat dan bergairah, maka dapat dipastikan bahwa tujuan yang telah ditetapkan perusahaan atau organisasi akan semakin mudah tercapai.

Tingkat kesadaran aparat yang tinggi Melaksanakan kegiatannya secara optimal, suatu organisasi memerlukan ketersedian sarana dan prasarana yang memadai baik dalam jumlah maupun kualitasnya berdasarkan tingkat kesadaran aparat bandar udara masih sangat kurang disiplin berhubungan kemampuan pegawai menyelesaikan masalah pekerjaan secara teratur dan bekerja dengan sungguh-sungguh karena sadar tugas merupak amanah yang akan dipertanggung jawabkan dunia dan akhirat, berarti kedisiplinan berkenaan dengan ketaatan seseorang yang secara sadar melaksanakan segala suatu yang telah ditetapkaan dan adanya motiwasi pada pegawai. Faktor penting yang harus diperhatikan yaitu harus diperhatikan adalah kedisiplinan aparat pemerintah sebagai ujung tombak negara dalam memenuhi kebutuhan masyarakat selain itu kedisiplinan pegawai merupakan hal penting dalam menunjang keberhasilan disiplin juga tidak kalah pentingnya dengan prinsipprinsip lainnya. Pendidikan (formal) merupakan suatu proses pengembangan kemampuan kearah yang diinginkan oleh organisasi bersangkutan untuk meningkatkan kemampuan dan keterampilan khusus seseorang atau sekelompok orang, juga bisa disebut sebagai usaha untuk meningkatkaan pengetahuan umum seseorang termasuk didalamnya penguasaan teori untuk memutuskan persealan-persoalan yang menyangkut kegiatan pencapaian tujuan perusahaan perlu disesuaikan dengan kebutuhankebutuhan pembangunan. Adanya suatu perencanaan tenaga kerja adalah untuk mencegah terjadinya penghamburan dana dan daya serta meningkatkan produksi dan produktivitas seoptimal mungkin.

Perancanaan yang efektif guna mencapai penerapan sistem kebijakan keselamatan dan kesehatan kerja cukup jelas dan dapat diukur 
sehingga pemimpin dapat bertanggung jawab dan sistem manajemen keselmatan dan kesehatan kerja telah di terapkan dengan baik. Pemantauan lingkungan harus mencakup baik internal dan komponen eksternal. Sementara sebagian besar organisasi merasa nyaman dengan pemindaian lingkungan internal, mereka masih memiliki lebih banyak kesulitan dengan bagian eksternal. Organisasi yang hanya melihat ke dalam masih kehilangan setengah dari persamaan utuh untuk membuat keputusan yang lebih efektif bagi perusahaan. Beberapa elemen yang biasa digunakan untuk memeriksa kondisi eksternal meliputi industri sebagai suatu keseluruhan (termasuk tren yang berdampak pada industri), dan tren sosial dalam empat bidang utama: ekonomi, teknologi, tren politikhukum, serta sosial-budaya. Ada tiga tingkatan strategi dibuat dalam organisasi yang lebih besar, yakni meliputi strategi perusahaan, bisnis, dan fungsional (atau operasional). Sementara strategi perusahaan akan menentukan bisnis apakah yang perusahaan akan benar-benar beroperasi di sana, strategi bisnis akan menentukan bagaimana perusahaan akan bersaing di masing-masing bisnis yang telah dipilih. Dan strategi tingkat operasional akan menentukan bagaimana masing-masing bidang fungsional (seperti sumber daya manusia atau akuntansi) benar-benar akan mendukung strategi-strategi bisnis dan korporasi. Semua strategi ini harus berkaitan erat untuk memastikan bahwa organisasi bergerak ke arah yang menyatu.

\section{KESIMPULAN}

Berdasarkan hasil penelitian yang telah dikemukakan pada bab sebelumnya, maka penulis dapat menarik kesimpulan bawah, 1. Penerapan sistem manajemen kinerja pegawai sudah efektif tapi belum maksimal. Hal tersebut dapat diketahui pada beberapa penjelasan sebagai berikut, a) Komitmen dan kebijakan penerapan sistem manajemen kinerja pegawai berjalan dengan berjalannya program yang telah di berikan di perusahaan berjalan dengan sprortif 
karena karyawan dibandara udara terbukti telah melaksanakan komitmen dan kebijakan sesuai yang telah diterapkan di Kantor. b) Perencanaan sistem manajemen kinerja pegawai yang berjalan dengan baik karena karyawan yang ada di bandara melakukan pekerjaan sesuai dengan perencanaan yang telah di terapkan di bandara sehingga kinerja pegawai dapat berjalan dengan efektif. c) Penerapan sistem manajemen kinerja pegawai sudah efektif dengan menciptakan hubungan harmonis bagi karyawan betul-betul kompotensi yang dimiliki sehingga mereka dapat memanfaatkan peluang yang diberikan oleh pemimpin.

Faktor penghambat penerapan sistem manajemen kinerja belum berjalan secara efektif karena dapat kita lihat di Bandara masih sangat a) kurangnya tenaga kerja sehingga ada pegawai yang merangkak dari kerjaan satu ke pekerjaan yang lain. b) kurang motivasi kerja berdasarkan kempuan yang dimiliki sehingga dapat mengerjakan pekerjaan kantor dengan kurang baik, dan tepat waktu tepat waktu dan menghasilkan suatu kinerja yang memuaskan, karena masih banyak karyawan yang kurang motivasi dalam melakukan pekerjaan. 3. Faktor pendukung penerapan sistem manajemen kinerja pegawai sudah berjalan dengan baik dilihat dari kemampuan yang dimiliki sehingga dapat mengerjakan pekerjaan kantor dengan baik. a) Tingkat kesadaran aparat yang semakin tinggi dalam dalam melakukan pekerjaan sehingga dapat terselesaikan, b) Tingkat pengetahuan yang semakin meningkat sehingga mampu berjalan dengan efektif dan efisien. c) Konsistensi waktu dengan adanya konsistensi waktu yang dimiliki karyawan sehingga karyawan mampu menghasilkan suatu kinerja yang memuaskan.

\section{DAFTAR PUSTAKA}

Amstrong, Michael dan Angela Baron. 2003.

Performance manajement. London: institute of personnel and development. 
Brotoharsojo, Hartanto \& Wungu, Jiwo,

2003, Tingkatkan Kinerja

Perusahaan dengan Merit

System, PT. Rajagrafindo

Persada, Jakarta.

Dessler, 2003. Human Resource Manajement, New Jarsey: Prentice Hall, Tenth Edition.

Mahsun, Mohamad, 2013. Pengukuran kinerja sektor public, Yokyakarta: Bpfe-yogyakarta

M. Sukaelan. 2003. Kecelakaan Kerja. Proseding Seminar Nasional Keselamatan dan Kesehatan Kerja. Yogyakarta. 20 September 2003

Siagian. 2003. Manajemen Sumber Daya Manusia. Bumi Aksara. Cetakan Kesepuluh. Jakarta.

Terry, dkk. 2000. Dasar-dasar Manajemen. Jakarta: PT Bumi Aksara

Udekusuma. 2007. Performance Manajement. University of Indonesia
Wibowo. 2007. Mea surement of operasional Risk on Indonesia Banking Industry: advance measurement Approach. University of Indonesia.

Wibisono, 2006. Aspek arkeologi dalam penelitian keramik: orasi pengukuhan Profesor Riset bidang arkeologi. Pusat penelitian dan pengembangan arkeologi nasional, Badan penelitian dan engembangan sumberdaya kebudayaan dan pariwisata, Departemen kebudayaan dan pariwisata 
